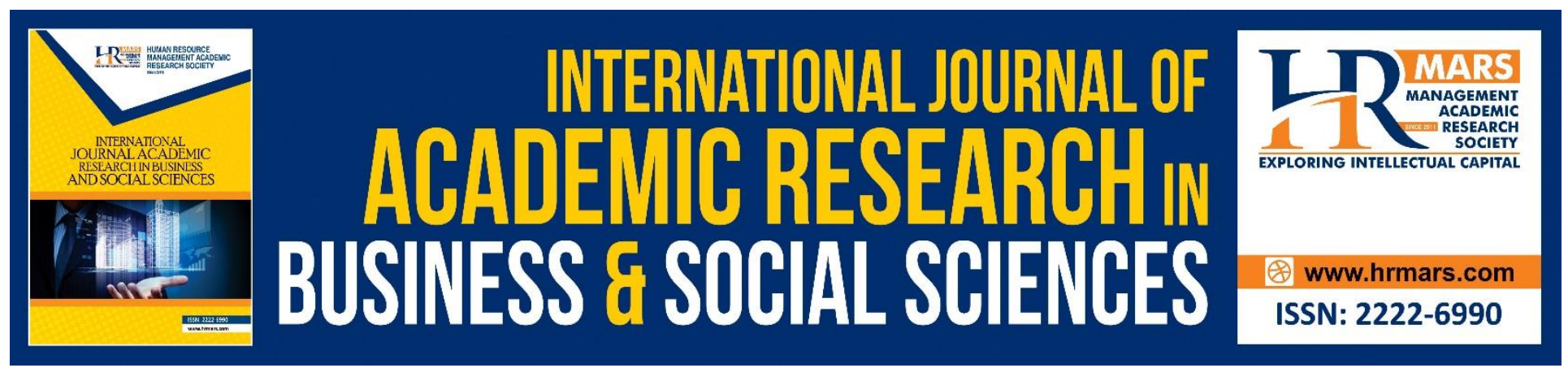

\title{
Factors Influencing Teacher Job Satisfaction in Malaysia
}

\author{
Ong Choon Hee, Mohammad Faiz Abdul Shukor, Lim Lee Ping, \\ Tan Owee Kowang, Goh Chin Fei
}

To Link this Article: http://dx.doi.org/10.6007/IJARBSS/v9-i1/5628

DOI: $\quad 10.6007 /$ IJARBSS/v9-i1/5628

Received: 29 Nov 2018, Revised: 19 Jan 2019, Accepted: 30 Jan 2019

Published Online: 04 Feb 2019

In-Text Citation: (Hee, Shukor, Ping, Kowang, \& Fei, 2019)

To Cite this Article: Hee, O. C., Shukor, M. F. A., Ping, L. L., Kowang, T. O., \& Fei, G. C. (2019). Factors Influencing Teacher Job Satisfaction in Malaysia. International Journal of Academic Research in Business and Social Sciences, 9(1), 1166-1174.

Copyright: () 2019 The Author(s)

Published by Human Resource Management Academic Research Society (www.hrmars.com)

This article is published under the Creative Commons Attribution (CC BY 4.0) license. Anyone may reproduce, distribute, translate and create derivative works of this article (for both commercial and non-commercial purposes), subject to full attribution to the original publication and authors. The full terms of this license may be seen

at: http://creativecommons.org/licences/by/4.0/legalcode

Vol. 9, No. 1, 2019, Pg. 1166 - 1174

http://hrmars.com/index.php/pages/detail/IJARBSS

JOURNAL HOMEPAGE

Full Terms \& Conditions of access and use can be found at http://hrmars.com/index.php/pages/detail/publication-ethics 


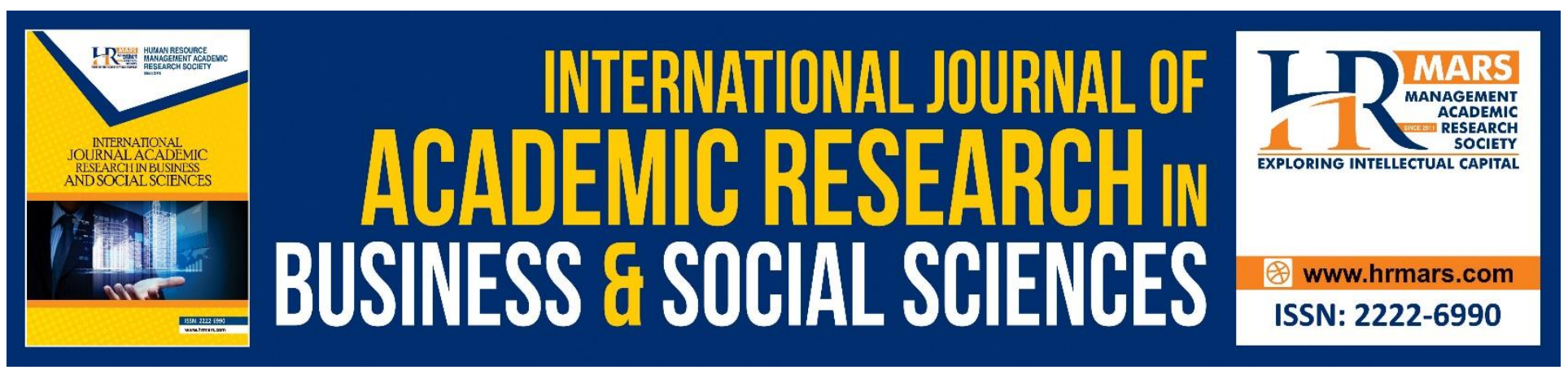

\title{
Factors Influencing Teacher Job Satisfaction in Malaysia
}

\author{
Ong Choon Hee, Mohammad Faiz Abdul Shukor, Lim Lee Ping, \\ Tan Owee Kowang, Goh Chin Fei \\ Azman Hashim International Business School, Universiti Teknologi Malaysia, Johor, Malaysia.
}

\begin{abstract}
Teachers are usually eager to implement what they learned during their training program. However, when they are in schools and face unexpected situations such as classroom conditions, state mandated programs, new educational conditions, goals, and reforms, they may feel that they have made a mistake choosing the teaching profession as their career. These challenges may lead to decreasing job satisfaction. In addition, a lack of professionalism, collegiality, and administrative support are among the reasons teachers leave their chosen career, even if they are really interested in the profession. The educational system in Malaysia is controlled by the government, in terms of the teacher placement system; student teachers who completed their training have limited choices for placement in schools. The theoretical framework in this study used Theory of Herzberg's TwoFactor to guide the research. These theories are used to explain the phenomenon of new teachers leaving the career during their probationary period. This study intends to explore and understand the challenges and experiences new teachers faced in schools after completion of their training.
\end{abstract}

Keywords: Job Satisfaction, Teacher, Herzberg Two-Factor Theory.

\section{Introduction}

Teaching profession has a reputable status in the community as teachers mould the children into good citizens who contribute to the future of a country. Teachers play an important role in fostering social and intellectual development of children in their formative years. The education that teachers convey plays an important role in determining the future prospects of their students. In schools, whether in preschool or high schools, private schools or public schools, teachers play a vital role to set the environment for students to develop into responsible adults. Indeed, teachers can make a huge difference in the life of student. Leaders in teacher education should prepare the most effective strategies for educating and training the nation's teachers before they are placed in schools. It seems that preparing teachers is not something that can be taken lightly. Specifically, the Malaysian Ministry of Education (MoE) does take into account all aspects including the selectivity of programs, the 
quality and content of the requirements, and the duration and timing of coursework and fieldwork to produce highly qualified teachers. As teachers are users and producers of teaching knowledge (Edwards, Gilroy, \& Hartley, 2002), pre-service teaching courses are essentially preparing student teachers to engage in systemic inquiry into children, youth, communities, schools, and teachinglearning processes as a formalized aspect of learning to teach (Schultz \& Oyler, 2006). These programs are important to orient student teachers before they move into practice. In addition, university graduates (non-teaching) who meet the requirements set forth by the Ministry can apply for the oneyear teaching course known as a postgraduate teaching course offered at any teaching institution throughout Malaysia. Students who are selected to enrol in the teaching program are fully sponsored by the Ministry. They are required to sign an agreement with the Ministry that states among other conditions that the student teacher could be placed in any school or teaching institution upon completion of their training (Ministry of Education Malaysia, 2011). After completion of the preservice course, student teachers fill out a placement form, provided by the School Management Division of the Malaysian Ministry of Education. Student teachers are to choose three states within the country for placement; however The School Management Division has the final decision over where an individual is posted based on the current needs for their specialty (Educational Planning and Research Division, 2008). New teachers are usually eager to implement what they learned during their training program (Inman \& Marlow, 2004). However, when they are in schools and face unexpected situations such as classroom conditions, state mandated programs, new educational conditions, goals, and reforms, they may feel that they have made a mistake choosing the teaching profession as their career (Inman \& Marlow, 2004). Consequently, teachers face many problems in terms of the emotional or physical aspects required to adapt to the new situation. These challenges may lead to decreasing job satisfaction. In addition, a lack of professionalism, collegiality, and administrative support (Inman \& Marlow, 2004) are among the reasons teachers leave their chosen career, even if they are really interested in the profession. Nevertheless, teachers benefit when teacher education programs and local school administration provide opportunities to interact and work with their mentors, colleagues, school administrators, and community. This may lead to teacher retention (Inman \& Marlow, 2004). In the Education Digest article, titled "Support new teachers and keep them teaching" South Carolina principal Dale Goff was quoted as saying that the most important thing a principal can do for new teachers is to offer continual support and opportunities to share their concerns and ideas. By providing support, new teachers realize that they are appreciated by their school principals. It is one of the reasons that new teachers remain in their chosen profession (Communicator, 2005).

\section{Teacher Job Satisfaction}

The teacher, who is noble in character, progressive and scientific in outlook, committed to uphold the aspirations of the nation, and cherishes the national cultural heritage, ensures the development of the individual and the preservation of a united, democratic, progressive and disciplined society. Education is one of the most powerful elements for bringing about changes required to achieve sustainable development (Educational Planning and Research Division, 2008). Teachers are the main actors in this process and teacher education training is a bridge for developing the capacities in teachers to deliver sustainable educational approaches. Job satisfaction in the work environment is 
derived by the attitudes and perceptions of teachers. It is measured in many different ways in the national surveys, and there is no consensus about the standard way to measure job satisfaction (European Foundation for the Improvement of Living and Working Conditions, 2007). One of the reasons for the continuing study in this topic is that positive and negative attitudes towards work may exert powerful effects on many forms of organizational behaviour. There are many factors that influenced job satisfaction. In terms of teacher job satisfaction, very few researches have been conducted to examine the factors that influence teacher job satisfaction. Therefore, there is a need to explore and identify significant factors that relate to it.

\section{Teacher Placement}

After teachers have completed their training programs, they will be placed in a school to practice what they learned in the training programs. In this context, the placement refers to the school for which teachers are placed or hired. Despite teachers can choose which schools they want to teach, the final decision often rests with the top management of the school district. New teachers often are placed in schools which lack of facilities, have fewer students, and are located in poverty areas. Generally, these situations frustrate new teachers and influenced them to leave early in their profession (Behrstock \& Coggshall, 2009). Texas Instrument (2012) also agreed that some new teachers leave early in their profession because they are placed in low-performing schools. It seems that they are not really needed by high performing schools. Most high performing schools hired experienced teachers to teach their students. As we know that new teachers have less experience and that influences their effectiveness. Lack of experiences could cause them to be placed in lowperforming schools. When the students did not perform well, they were responsible for students' performance. New teachers may feel frustrated and decided to leave their profession in the beginning of their career (Sparks, 2012). Most students from low-performing schools came from the lower socioeconomic status and were not conscious of the importance of education. New teachers faced difficulties to educate them to perform well because they did not really pay attention in the classroom. Hence, it may cause frustration until they decide to leave the profession in the early stage (Johnson \& Birkeland, 2003). Based on the above discussion, it is proposed that:

Proposition 1: Teacher placement has a significant relationship with teacher job satisfaction.

\section{Principal Leadership}

Generally, when employees are satisfied towards their leaders or supervisors, it really affects the organization where it can increase productivity, decrease absenteeism, and promote smoother working relationships (Herzberg et al., 1959). As a leader in schools, the school principal is the main factor in determining the quality of education in the school. In this respect, the principal always communicates and cooperates with teachers to increase school performance. No matter what is the leadership style the principal practices, it can affect teachers' job satisfaction. Whether they are managing a team at work, captaining their sports team, or leading a major company, the leadership style is crucial to the team success (Goleman, Boyatzis, \& McKee, 2002). Democratic style encourages employees to be part of decision making. However, the leaders maintain the final decision-making authority. This is normally used when the leader has a part in decision making and employees also 
have a say. A leader is not expect to know everything and that is why a leader often employs knowledgeable and skilful employees. Since leadership behaviours of principals are one of the factors positively influencing teachers' job satisfaction (Miears, 2004), the effect of different leadership style on job satisfaction has been examined. Many researches have been done to determine the relationship between principal leadership style and teachers' job satisfaction. Cerit (2009) completed a study to determine servant leadership behaviours of primary school principals on teacher's job satisfaction. The participants of his study consisted of 700 primary school teachers at 29 schools located in the province of Duzce, Turkey. 595 teachers who responded to the questionnaire comprised of various educational levels and experiences. The questionnaire was divided into two sections where the first section has 60 items aiming to determine servant leadership behaviours of the primary school principals, and the second one has eight items to determine the level of teachers' job satisfaction. The result of his study showed that there was a positive and significant relationship between servant leadership behaviours of the principals and teachers' job satisfaction. Therefore, it is proposed that:

Proposition 2: Principal leadership has a significant relationship with teacher job satisfaction.

\section{School Environment}

Workplace condition plays an important role to make employees happy to work with their colleagues. When employees feel dissatisfied at work, they are less committed and will look for other opportunities (Taylor \& Tashokkari, 1995). In Brown and Wynn's study (2009), the results showed that school climate was one of the factors that make new teachers happy in their school and decide to remain in their respective school. If this conducive environment is not available, they may emotionally withdraw from the organization (Lok \& Crawford, 2003). A conducive environment encourages teachers to put extra effort in getting their job done, working in a discretionary manner, and contributing directly to the organizational growth (Kim \& Loadman, 1994). Lee, Dedrick, and Smith (1991) noticed that a supportive environment and sufficient classroom autonomy promote efficacy and satisfaction in teachers' career path. Lee, Dedrick, and Smith (1991) found that smaller class size affects teacher job satisfaction. Teachers feel more satisfied teaching in smaller class size compared to teachers who teach in bigger class size. Teacher job satisfaction is also associated with class control along with the selection of textbooks, instructional content, teaching techniques, discipline of the students, and assignment of homework. It is also associated with the types of students and their level of ability. Hence, it is proposed that:

Proposition 3: School environment has a significant relationship with teacher job satisfaction.

\section{Salary and Benefits}

According to Lee, Dedrick, and Smith (1991), the result of their study showed that salary was unrelated to teachers' job satisfaction. In their study, higher salary was not an indicator of teacher job satisfaction. However, the results of the studies conducted by Hanushek, Kain, and Rivkin (2001) and Guarino, Santibanez, and Daley (2006) showed that the higher the teachers earn, the higher satisfaction they obtain. As a result, they are willing to stay in the profession. In order to enhance 
INTERNATIONAL JOURNAL OF ACADEMIC RESEARCH IN BUSINESS AND SOCIAL SCIENCES

Vol. 9, No. 1, Jan, 2019, E-ISSN: 2222-6990 @ 2019 HRMARS

teacher quality, policies that reward teachers based on performance may be more effective than policies that reward teachers based on credentials (Rockoff, 2004). By rewarding teachers based on their performance, they are more satisfied and decide to remain in the profession. Similarly, Billingsley (1992) also addressed that salary has significant relationship with teacher job satisfaction. Salary and other benefits are important to keep teachers in the profession. The more remuneration and benefits the teachers obtain, the more they are satisfied. According to Fioviello (2011), one of the four real reasons new teachers leave the profession is due to low salary. A lack of competitive salary compared to workload in schools causes them to decide to leave the profession. They do not only teach but also need to perform administrative works and assist in curricular activities. Therefore, it is proposed that:

Proposition 4: Salary and benefits have a significant relationship with teacher job satisfaction.

\section{Theoretical Framework}

Based on the write up and previous findings in the literature review, a theoretical framework was developed as presented in Figure 1.

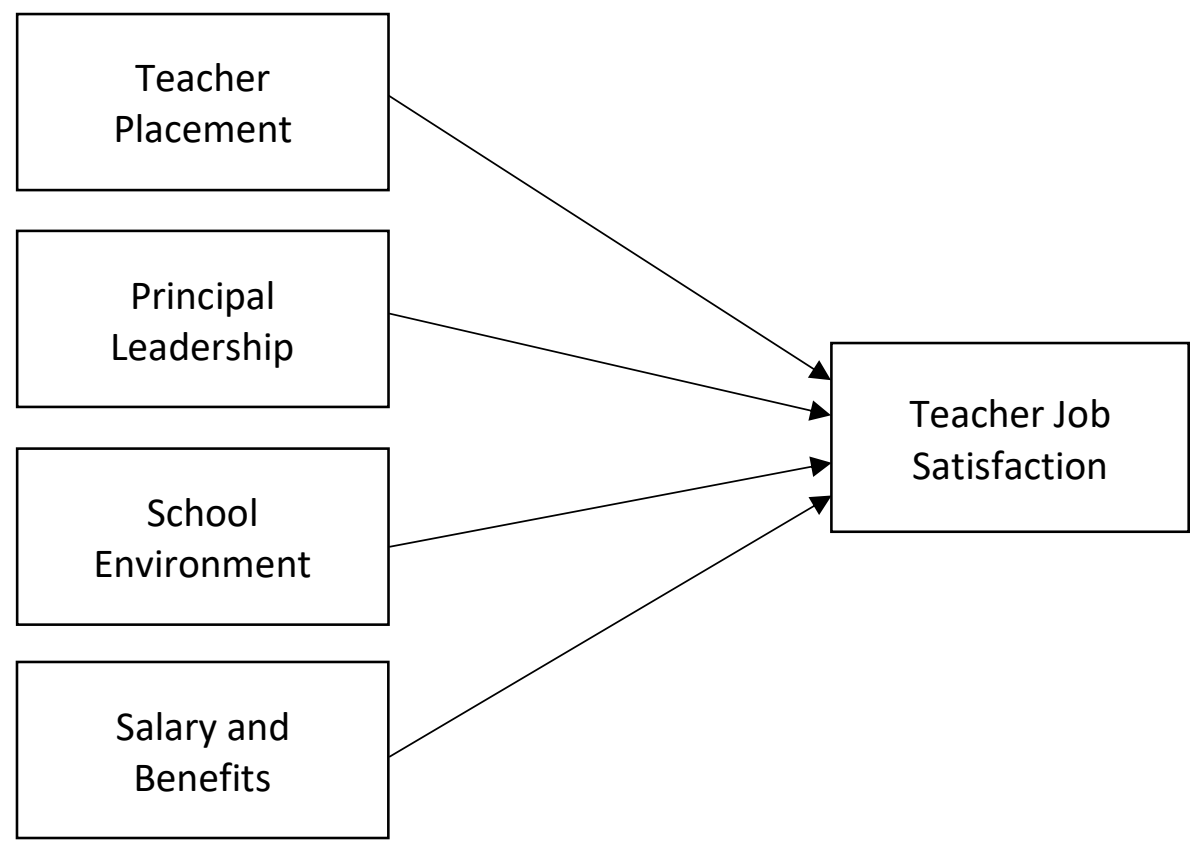

Figure 1: Proposed Theoretical Framework

\section{Research Implications}

The purpose of this study is to explore and understand the challenges and experiences that lead to teachers' job satisfaction after completion of their training. As new teachers, they are excited to implement what they learned in teaching programs (Inman \& Marlow, 2004). However, if they face unexpected challenges and these situations may influence their job satisfaction at the workplace. By 
understanding these challenges and experiences, a clear scenario can be gained to present these challenges to the policy makers, practitioners, and any divisions under the Ministry of Education. In Malaysia, the phenomenon of teachers leaving the profession is increasing from year to year. However, statistical information of this issue is not readily accessible. This phenomenon may adversely affect the nation because new teachers are needed to educate the young generation in the country. Therefore, understanding teachers' job satisfaction in the early stage can prevent them from leaving the profession. Based on the findings, policy makers may review the selection process of teacher candidates, the teaching programs, the placement process, and the professional development programs to improve the job satisfaction level. The goal is to ensure teachers in the next generation to remain in the profession. Even though the researcher knows it is difficult to make a rapid change in the educational system, but by conducting this study, it can assist the Ministry of Education to review the system related to teacher's matters as an effort to enhance teacher's job satisfaction. To do so, they need a well-planned effort to ensure that it runs smoothly. The results of this study may have positive implications to retain new teachers in their profession in Malaysia. The findings of the current study support the idea that it relates to organizational issue (including leadership styles and practices among school leaders, school expectation, heavy workload, lack of support, lack of professional development courses attended), personal issue (financial), and placement system issue that influence teachers' job satisfaction. The finding is expected to suggest that schools should be open to accept criticism and suggestions from teachers, particularly new teachers to change for better.

\section{Conclusion}

Although past research has provided many insights into the factors that influence teacher career decisions, little is known about which unfulfilled needs cause teachers to leave the profession and which job condition makes them satisfied or dissatisfied. Understanding multiple factors that lead to teacher's job satisfaction may help identifying changes needed to support teachers' retention (Liu \& Ramsey, 2008).

\section{Acknowledgements}

The authors would like to thank the Malaysian Ministry of Higher Education and Universiti Teknologi Malaysia (GUP-Vot: 14J81) for providing financial support to publish this paper.

\section{References}

Behrstock, E., \& Coggshall, J. G. (2009). Teacher hiring, placement, and assignment practices. National Comprehensive Center for Teacher Quality: Washington, DC.

Billingsley, B. S. (1992). Predictors of commitment, job satisfaction, and intent to stay in teaching: A comparison of general and special educators. The Journal of Special Education, 25(4), 453-

\section{1.}

Brown, K. M., \& Wynn, S. R. (2009). Finding, supporting, and keeping: The role of the principal in teacher retention issues. Leadership and Policy in Schools, 8(1), 37-63.

Cerit, Y. (2009). The effects of servant leadership behaviours of school principals on teachers' job satisfaction. Educational Management Administration \& Leadership, 37, 600-623. 
INTERNATIONAL JOURNAL OF ACADEMIC RESEARCH IN BUSINESS AND SOCIAL SCIENCES

Vol. 9, No. 1, Jan, 2019, E-ISSN: 2222-6990 @ 2019 HRMARS

Communicator. (2005). Support new teachers and keep them teaching. Education Digest, 70(9), 4042.

Educational Planning and Research Division. (2008). Education in Malaysia: A journey to excellent. Kuala Lumpur: Ampang Press.

Edwards, A., Gilroy, P., \& Hartley, D. (2002). Rethinking teacher education: Collaborative responses to uncertainty. London: Routledge Falmer.

European Foundation for the Improvement of Living and Working Conditions. (2007). Measuring job satisfaction in surveys- Comparative analytical report. Dublin, Ireland: Eurofound.

Fioviello, P. (2011). Four real reasons why teachers leave the profession.

Goleman, D., Boyatzis, R., \& McKee, A. (2002). Primal leadership: Learning to lead with emotional intelligence. Boston, Massachusetts: HBS Press.

Guarino, C. M., Santibanez, L., \& Daley G. A. (2006). Teacher recruitment and retention: A review of the recent empirical literature. Review of Educational Research, 76(2), 173-208.

Hanushek, E. A., Kain, J. F., \& Rivkin, S. G. (2001). Why public schools lose teachers (Working paper 8599). Cambridge, MA: National Bureau of Economic Research.

Herzberg, F., Mausner, B., \& Snyderman, B. (1959). Motivation to work. New York: Wiley and Sons, Inc.

Inman, D., \& Marlow, L. (2004). Teacher retention: Why do beginning teachers remain in the profession? Education, 124(4), 605-614.

Johnson, S. M., \& Birkeland, S. E. (2003). Pursuing a "sense of success": New teachers explain their career decisions. American Educational Research Journal, 40(3), 581-617.

Kim, I., \& Loadman, W. E. (1994). Predicting teacher job satisfaction. Columbus, OH: Ohio State University.

Lee, V. E., Dedrick, R. F., \& Smith, J. B. (1991). The effect of the social organization of schools on teachers' efficacy and satisfaction. Sociology of Education, 64, 190-208.

Liu, X. S., \& Ramsey J. (2008). Teachers" job satisfaction: Analyses of the teacher follow-up survey in the United States for 2000-2001. Teaching and Teacher Education, 24, 1173-1184.

Lok, P., \& Crawford, J. (2003). The effect of organizational culture and leadership style on job satisfaction and organizational commitment: A cross national comparison. Journal of Management Development, 23(4), 321-338.

Miears, L. D. (2004). Servant-Leader ship and Job Satisfaction: A Correlational Study in Texas Education Agency Region X Public Schools. Dissertation Abstracts International, 65(9): 3148083. Ministry of Education Malaysia. (2011). Educational policy.

Rockoff, J. E. (2004). The impact of individual teachers on student achievement: Evidence from panel data. The American Economic Review, 94(2), 247-252.

Schultz, B. D., \& Oyler, C. (2006). We make this road as we walk together: Sharing teacher authority in a social action curriculum project. Curriculum Inquiry, 36(4), 423-451.

Sparks, S. D. (2012). New teacher placement, retention, can exacerbate achievement gaps. Education Week.

Taylor, D. L., \& Tashakkori, A. (1995). Decision participation and school climate as predictors of job satisfaction and teachers" sense efficacy. Journal of Experimental Education, 63(3), 217-230. 
INTERNATIONAL JOURNAL OF ACADEMIC RESEARCH IN BUSINESS AND SOCIAL SCIENCES

Vol. 9, No. 1, Jan, 2019, E-ISSN: 2222-6990 @ 2019 HRMARS

Texas Instrument. (2012). Getting and keeping the teachers we need in the places we need them: Teacher recruitment, retention, and assignment.

\section{Corresponding Author}

Ong Choon Hee

Corresponding Author: ongchoonhee@gmail.com 